\title{
Major Irrigation in India: Incompetent Bureaucracy and Hobbesian State of Nature in Water Management
}

\author{
Bathini Munirathnam*, Tokusou Saito**, \\ Atsushi Matsuoka** \\ * United Graduate School of Agriculture, Ehime University. \\ ** Faculty of Agriculture, Ehime University.
}

\begin{abstract}
Summary: India has invested millions of rupees in water resources development since independence. But the returns are very low. It is assumed that institutional and managerial problems are inhibiting for efficient use of water. In India bureaucracy is responsible for planning, designing, construction, operation, maintenance and management of large irrigation projects. Inefficient bureaucracy has been responsible for chaos and lawlessness in the water management and water distribution. Largely, the officials are docile, inactive and corrupted. Besides, they are too proudy, refuse to learn and inadequately trained to carry integrated management of agricultural water. Moreover, the conditions like lack of proper facilities, external interference, financial stringency are not congenial to work environment. Now it is high time for the government to bring alternative institutions by creating efficient and committed bureaucracy on the one hand and reducing the burden on the state by transferring management partially to beneficiaries on the other.
\end{abstract}

Key words: India, Irrigation, Bureaucracy, Water Management, Efficiency.

\section{Introduction}

Increasing irrigation facilities is the pre-condition to enhance agricultural productivity. Its importance is all the more in India because of gambling monsoons, low and singular rainfall. Indian government categorized irrigation as one of the highest priority sectors and it accounts for about 8 to 9 percent of total investment in India and about 11 percent of plan expenditure. But the returns from irrigation is not as expected. The overall average for food grain yields in India is dismal 2 tones/ha i.e., one third of that of Japan. It is because investing and creating potential will not assure of higher productivity in agriculture. In developing countries as well as in India, there are many environmental, social and institutional factors which are affecting efficient utilization of these scarce resources.
In India, major and medium water resources projects are constructed, operated, maintained and managed by bureaucracy. A centralized and large irrigation bureaucracy has been created for managing the canals but the projects are operated inefficiently and chaos prevailed in water control and distribution. An attempt has been made in this paper to high light how serious is the problem of canal mismanagement in India in relation to bureaucratic inefficiency. Since bureaucracy is single handedly responsible for canal management in India, enough space and time has been devoted to analyze bureaucratic structures and patterns, communication facilities, bureaucracy-politicians-farmers relation and their influence and impact on water deliveries, farmers' interference above the outlet level, water theft and shortages, corruption, canal repair and maintenance problems. Besides, 
The index map of Tungabhadra Project Right Bank Low Level Canal

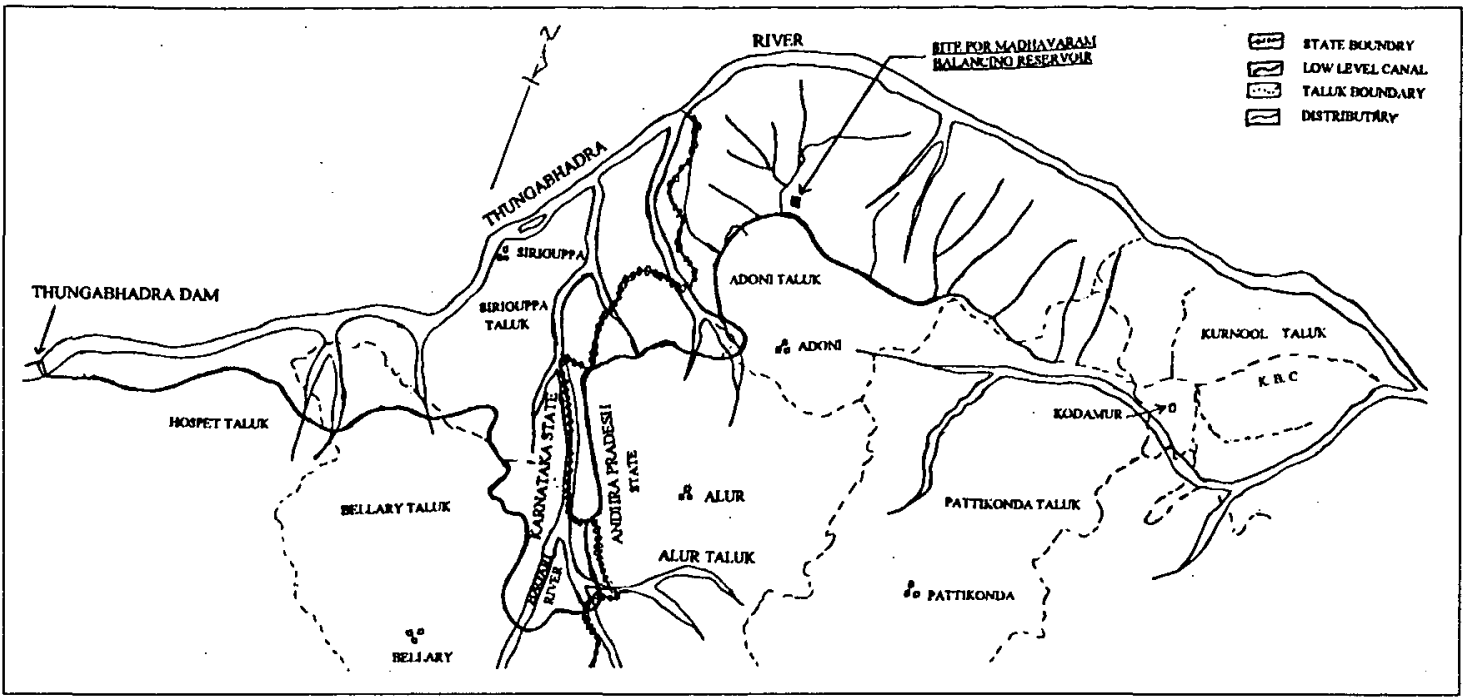

reasons for such existing conditions have been discussed. Moreover, an understanding has been reached that by introducing changes in management and only carrying minor modifications in physical structures, the created potential could be better utilized, equity could be brought between topenders and tail enders, productivity of food grains could be increased.

\section{Description of the study area and methodology}

This study is based on the survey conducted on Right Bank Low Level Canal under Tungabhadra reservoir in March 1997(See Map). The Tungabhadra project is located in Bellary district of Karnataka. Since the area receives low rainfall and drought prone, the project designers felt that the benefits should be spread over a large area to reduce the impact of droughts and possible instigation of migration to urban areas. ")

The project supplies water to rain shadow areas, Raichur and Bellary districts of Karnataka; Kurnool and Anantapur districts of Andhra Pradesh by utilizing four main canals. Among four, three are running very long distances. The Table 1 provides the details of length and capacity of the three main canals.

All the main canals have been lined(some parts of Right Bank Low Level Canal is yet to be completed) but the branch canals and field

Table 1

Various particulars of main canals

\begin{tabular}{|llll|}
\hline Canal particulars & $\begin{array}{l}\text { Right Side. } \\
\text { Lower Level Canal }\end{array}$ & $\begin{array}{l}\text { Right Side. } \\
\text { Higher Level Canal }\end{array}$ & $\begin{array}{l}\text { Left Side. } \\
\text { Lower Level Canal }\end{array}$ \\
\hline $\begin{array}{l}\text { Total length } \\
\text { Upto to Board Limit }\end{array}$ & $\begin{array}{l}349.00 \mathrm{~km} . \\
250.58 \mathrm{~km} .\end{array}$ & $\begin{array}{l}196.00 \mathrm{~km} . \\
105.43 \mathrm{~km} .\end{array}$ & $227.00 \mathrm{~km}$ \\
Bed width & $21.95 \mathrm{~m}$. & $19.82 \mathrm{~m}$. & $25.61 \mathrm{~m}$ \\
F.S. Depth & $3.05 \mathrm{~m}$. & $3.66 \mathrm{~m}$. & $4.27 \mathrm{~m}$ \\
Velocity & $0.91 \mathrm{~m} / \mathrm{sec}$ & $1.37 \mathrm{~m} / \mathrm{sec}$ & $1.37 \mathrm{~m} / \mathrm{sec}$ \\
Fall & 1 in & 1 in & 1 in \\
& 10560 & 10000 & 10000 \\
\hline
\end{tabular}

Source: Tungabhadra Board. 
Table 2

The area localized under different canals

(in acres)

\begin{tabular}{|c|c|c|c|c|c|c|}
\hline \multirow[t]{2}{*}{ Particulars of area } & \multicolumn{2}{|c|}{ Left Bank Canal } & \multicolumn{2}{|c|}{ Right Bank L.L.C. } & \multicolumn{2}{|c|}{ Right Bank H.L.C. } \\
\hline & \multicolumn{2}{|c|}{ Karnataka } & \multicolumn{2}{|c|}{ Kamataka Andhra Pradesh } & Kamataka & $\begin{array}{l}\text { Andhra } \\
\text { Pradesh }\end{array}$ \\
\hline Gross commanded area & \multicolumn{2}{|c|}{1080000} & \multicolumn{2}{|r|}{860000} & \multicolumn{2}{|c|}{1343000} \\
\hline Cultivable commanded area & \multicolumn{2}{|c|}{800000} & \multicolumn{2}{|r|}{750000} & \multicolumn{2}{|c|}{936000} \\
\hline Localized areas & 1080 & 580000 & 92345 & 148724 & . 199534 & 188766 \\
\hline Kharif & 1080 & 260000 & 17714 & 36096 & 199534 & 188766 \\
\hline Perennial & & 45000 & 15330 & & & \\
\hline
\end{tabular}

Source: Tungabhadra Board, Technical Report on Tungabhadra Project, vol.1, Tungabhadra Dam, p.49.

channels are not lined. Since the capacity of the dam is too small to cover the total area, a special criteria had been followed to localize the command area of the project. The Table 2 provides the area localized under various canals. Under Right Bank Low Level Canal, one third of the total culturable command area is localized. Since irrigated wet crops like paddy and sugarcane consume more water, the preference was given to irrigated dry crops. More than three fourth of the area localized was designated for .irrigated dry crops. In Kharif ${ }^{2)}$ the proportion of area designated to irrigated wet crops is more than in Rabi ${ }^{3)}$ season. Generally the crops grown in the irrigated wet area are paddy and sugarcane. Groundnut, sunflower, jawar, kora, cotton, maize, ragi, vegetables etc. are grown in the irrigated dry area.

In order to analyze the efficiency, we need to have data on various indicators. But there is no data on the productivity of the water, water losses at various levels, area of unauthorized cultivation, iwater theft, exact delivery of water in each outlet, the yearly acreage of approved and unapproved cropping pattern. So sometimes we had to depend on the estimates made at the stage of design of the canal and memory based approximate estimates made by the officials. To overcome some of the weaknesses we have undertaken a field trip to canal command area and made simultaneous interviews with irrigation bureaucracy on the one hand and the farmers on the other. Since this study is on bureaucracy, the subject has been approached from the point of view of political economy and both inductive and deductive logics have been used.

\section{Nature of Irrigation Bureaucracy and water management}

Since irrigation 'schemes were small, village community used to manage them during preBritish period. British initiated extensive large scale canal irrigation and they were managed by colonial bureaucracy ignoring local participation. ${ }^{4}$ Even after the independence, the local bureaucracy followed the same pattern of administration and knowingly allowed the age old traditions to get defunct. ${ }^{5)}$ Now a centralized bureaucracy is responsible for managing irrigation projects. They are government employees directly receiving the salaries from the government. There is no linkage between their emoluments and performance of the project or collection of water rates from the farmers. The bureaucracy is organized on hierarchical basis as Chief Engineer General on the top(See the Chart). He is placed in the capital city of the state. The branches of Irrigation Department is located in many regional cities and towns. The heads of operation and maintenance division are placed near the command area. The staff get transfers from one place to another very frequently. 
Delivering the water up to the outlet is the responsibility of the staff.

The Right Bank Low Level Canal is directly managed by the Tungabhadra Board upto 250 kms. distance. The regional offices of the canal management division are located at Bellary and Adoni towns. The Executive Engineer is the highest regional officer. The lowest officer in the rank is Junior Engineer covering at an average of $16 \mathrm{kms}$. of canal. He is assisted with 2 Work Inspectors and 3 Laskars(manual workers assist irrigation staff). The Work Inspectors and Laskars are appointed by the Tungabhadra Board and gets transfers at an average of five years. The Junior engineer and above officers are deputed from Andhra Pradesh and Karnataka State governments and they get transfers at an average of three years.

The structure of state's Irrigation Department

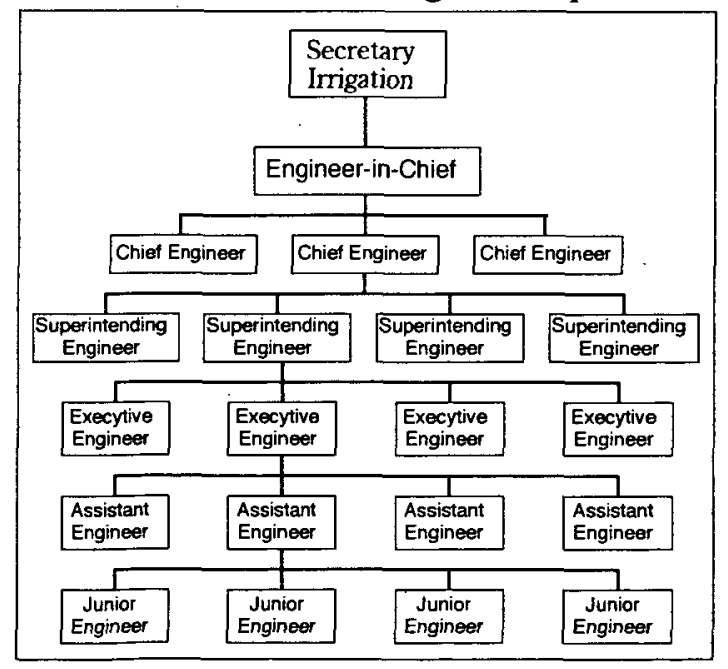

\section{Performance criteria}

\subsection{Adequacy}

Adequacy of water is essential to protect soil moisture and increase yields. ${ }^{6}$ Farmers complain that the scarcity of water is felt in almost all the years. It is too serious at the end of each cropping season in October-November and March-April. The problem has become more rampant due to stealing of water and failure to check growing of more water consuming crops. Farmers and officials unanimously agreed that water consuming crops especially paddy and sugarcane have increased.

\subsection{Reliability}

Reliable water supply would permit farmers to plan agricultural activities and maximize productivity. No farmer takes risk under unreliable conditions of water supply. Bureaucracy can not assure reliable supply of water due to uncheckable water theft and unauthorized cultivation. There is no account of actual flow of water in different levels of canals, wastages of water at each level, water deliveries under the each outlet and water requirement of each crop under different atmospheric conditions. So, unreliable water supply has its impact on overall productivity of agriculture.

\subsection{Timeliness}

Predictable water supply allow farmers to plan their farm activities by minimizing wastages and maximizing productivity. ${ }^{\text {" }}$ Predictability means farmers should know when and what quantities of water they get. According to the findings of the survey, fifteen days advance notices are given about the release of water to the canals through District Collectors. The notices are supposed to be circulated to all the Mandal offices. Since Mandal Officer is always busy with many other things it is not properly conveyed to farmers. Besides, fifteen days advance notices are too short to allow farmers to plan cropping pattern. It happens many times that farmers would come know the arrival of water only after seeing it in the canal.

\subsection{Flow rate(tractability)}

Very small stream sizes may lead to uneven application of water with large percolation losses. Very large stream sizes are also problem which 
creates soil erosion, damaging crops and bunds, siltation etc. ${ }^{8)}$ The normal rate of flow is 0.716 meters per second in the head canal and 0.3 meters per second in the channels. But in actual practice one goes from head to tail the flow rates are quite varied and tail-end farmers do not get water at all. If farmers come to know that water would be closed in the canals, the upper region farmers start bunding the canal to store the water that enables farmers to give last additional watering to their crops.

\subsection{Cost recovery}

As it is the case with rest of India, the cost recovery rates are poor in the case of Tungabhadra project also. According to Tungabhadra Board officials, the recovery rates are much below the maintenance costs. It is because the water rates are lower and 20 to 25 percent of the area cultivated is unauthorized for which government do not get anything. Besides, there is hardly any fines collected on unauthorized cultivation. Though there is no any data on recovery rates separately for this canal yet the national and state overall irrigation recovery rates show that it is much lower than O\&M expenditures.

\subsection{Equity}

When water supply is less than demand, the equity issues crop up. Equity shows fairness in distribution. ${ }^{\text {9) }}$ The availability of water is too varied from head to tail regions. Besides, economically more beneficial crops are grown in the head region and dry land crops are grown in the tail regions. The situational disadvantages are supposed to have been modified and marginalised by the managerial abilities but failures are attributable to incompetency. Besides, according to the officials, they provide water to the ayacut(cultivated land) but there is no account who is taking the water. Distribution within the village is a serious problem.
Besides, there is no data on the productivity of the water under the canal and difficult to judge the criteria called convenience. It has been deduced here that because of lack of training programs on farm management practices and water extension activities, over-irrigation and under-irrigation problems, unpredictable and inadequate nature of water supplies, the productivity is lower. In the case of continuous flows, it is difficult to practice convenience of supplies.

\section{Reasons for lower efficiencies}

\subsection{The Problems from within}

\subsubsection{No commitment}

The monitoring, supervision and evaluation of canals is very haphazard, irregular and limited. Many officials are simply docile or inactive. Only small percent of officers are committed but they have to face lot of hurdles. The higher grade officials are busy in lobbying for their transfers or getting civil contracts to their kith and kin. They find it troublesome to go to their offices every day. Besides, most of the irrigation officials stay in the cities and towns and take no interest in visiting the canal area. Though the transport facilities are not provided to Junior Engineers (JE) and Work Inspectors(WI) but the transport allowance of Rs. 500/- to JEs and Rs. 300/- to WIs is provided monthly. In spite, they occasionally visit the field area. Even if they have opportunity, they visit only that part of the canal which could be easily approachable by the road. As a result, there is no monitoring of flow rates in the main, subsidiary canals and water courses. So there is lack of even minimum data on important areas related to management. If such losses are higher than the designed values, the reliability of water available to the farmers at the tail of main canal or water courses declines significantly. ${ }^{10}$ Moreover, most of the irrigation employees are civil engineering diploma or degree holders and they have only theoretical understanding. There 
is lot of difference between the theory they have learnt from universities and colleges and actual practice. After joining job their elitism and pride prevents them to go in the field and learn from actual practice. Besides, there is lack of government initiatives to launch in-service training programs for employees. Moreover, their understanding regarding water saving and water management in relation to agriculture is also limited. ${ }^{11)}$ This lacuna has been recognized by many other studies.

\subsubsection{Communication gap and lack of feed back mechanisms}

There is an information and communication gap among employees on the one hand and employees and farmers on the other. Major decisions have been taken without consulting the junior staff. Even after taking decisions at the top the results are not conveyed to lower level employees. For example, a decision had been taken at the Tungabhadra Board meeting to extend supplies for two more weeks but it was not conveyed either to lower employees or farmers. Besides, bureaucrats show little interest in finding suitable development pattern and farmers' conveniences. ${ }^{\text {12) }}$ For example, in India, Command Area Development(CAD) officials determine land localization/water distribution policy and cropping pattern solely based on soil, climate, and the availability of water for maximizing cropwise production without consulting the farmers. ${ }^{13)}$ Unlike in the developed countries, the feed back mechanism is very weak in India. ${ }^{14)}$

\subsubsection{Corrupt practices}

Rampant corruption among the irrigation bureaucracy has been noticed as one of the major causes of inefficiency. The pattern of localization and water theft provides an opportunity to the corrupt officials to raise large amounts of illicit revenue by agreeing to supply, or agreeing not to attempt to cut off supply. ${ }^{15\rangle}$ Wade describes the common trick being followed by employees is to increase the uncertainty of water deliveries and then collect payments for guaranteeing delivery. ${ }^{16}$ The corruption is in the form of both cash and kind. The amount varies depending on the circumstances and persons. The important aspect of the corruption is that it is the moral responsibility of the concerned official to inform farmers in advance in the case of checkings. But according to the officials, the farmers are threatening them if they take any action to check unauthorized cultivation or water theft. Whatever may be, the fact is that after receiving fairly large amount of salaries, their contribution to irrigation efficiency is really questionable. Instead, they became burden on the state.

\subsection{Unfavorable conditions}

\subsubsection{Non-cooperation from farmers}

Large part of the area localized under dry land crops. Officials and government insist them to cultivate short duration crops but farmers bent on cultivating only paddy and groundnut. During Kharif season farmers extend water requirement period 15 days more than normal schedule and similarly in the Rabi season the officials asked farmers to grow such crops so that they can reap it before 15th March. But farmers demand water till 30th March. Every year it happens because farmers are reluctant to follow appropriate recommended cropping pattern. Besides, if one farmer violates the set cropping pattern the neighboring farmers have to follow him because the land adjacent to paddy field gets saline and not useful to grow dry land crops. Therefore, one ambitious farmer indirectly forces neighbors to grow paddy or other wet land crops.

\subsubsection{External interference in the affairs of bureaucracy}

In a limited supply and unrestrained circumstances, farmers struggle to obtain better supplies by stealing water, breaking the gates, breaching the 
banks, bribing the officials; so compounding the overall situation. ${ }^{17}$ In the presence of incompetent bureaucracy, everybody wants to grab whatever they can get. Since there is lot of non-localized area in every village, it became easy for the farmers to irrigate their lands which are nearby canal. Mostly water theft takes place in the night. In the night many farmers pump water from canal to the well and later the water would be used depending upon the necessity. Many other farmers use 10 to 15 meters of flexible pipes and draw water directly from the canal without using energy. If the farmer's land is much above than canal base he would dig small pit to draw water easily. In about $250 \mathrm{kms}$ distance, more than 3000 such flexible pipes are being used by farmers to irrigate non-localized lands. In the case of night checkings, if one farmer notices officials he informs others by vigiling.

Unauthorized farmers are very much unionized, any threat to their interests would lead to violence. They often break the locks and gates. According to employees, once they tried to stop the water theft but farmers tried to break the canal wall. Later officials became scarred that the cost involved in repairing the canal would be high and getting funds from the government is difficult and time consuming so they had to stop further action. Besides, it is also common for the farmers to threaten even higher officials if they question their interests.

In a populist democracy like India where politicians appeal voters by providing short term benefits. It is easy for the farmers to approach these politicians. If water is stopped to unauthorized cultivators, farmers immediately go to local politicians who are representing them. These politicians use all their means - appealing, lobbying and threatening - to get water to their voters. If local officers reject their demands they go to state capital to lobby for water. On many occasions, the Members of the Legislative Assembly go to Chief Minister and got special sanction for water on appealing to humanitarian grounds that the crops are drying up.

\subsubsection{Inadequate supporting services}

The transport and communication facilities provided to the staff are insufficient. Most of the vehicles provided to irrigation staff are under repair. Only one or two are in running condition. But there is no fund for gasoline. The telephones are also in out of order. When we made interview with Executive Engineer(EE), he told us that his telephone has not been working for 4 months. He has to use private telephones by paying from his pocket. If somebody wants to contact him it is not possible. Given the facilities, it is difficult to operate under the conditions of exigencies. Throughout the canal area only few important places are provided with wireless or public telephones.

\subsubsection{Scarcity of funds and financial stringency}

Scarcity of finances at central and state level adversely affected water resources management activities. According to government classification, the repair and maintenance falls under non-plan expenditure. Since the central government is under constant pressure to reduce non-plan expenditure, budget allotment to repair and maintenance has been reduced. This has affected the routine cleaning and repair of canals. Besides, there are lot of institutional and procedural problems in actually drawing money from the state budget. One has to make an application stating the financial requirements to the government. After making an application one has to follow it up. Otherwise it would be held up somewhere. In order to move the application, the irrigation officials have to make so 
many trips to state capital for getting sanctions. 10 percent of the funds to be sanctioned has to be spent in the process by way of corrupting government officials. So it is difficult to carry maintenance activities sincerely.

\section{Lower water rates and recovery problem}

The water rates prevalent in Andhra Pradesh since 1986 are shown in the Table 3 . The water rates are much below the current expenditures involved in operation. This is because state governments are hesitant to increase water rates. The result, for instance, water rates in Tamil Nadu were last revised 30 years back. In Punjab, Kerala, Haryana, Jammu and Kashmir and Himachal Pradesh, there has been no change in the rates since the mid 1970s. Several other states(Andhra Pradesh, Bihar, Gujarat, Karnataka, Madhya Pradesh, Orissa, Rajasthan, Uttar
Pradesh and West Bengal) announced revisions during 1981-86, but in some cases like Gujarat and Karnataka, the implementation of revised rates was held up by the governments, and in the case of Andhra Pradesh implementation is held up because of stay orders from the courts. ${ }^{18)}$

But during the same period the current expenses on operation and maintenance increased so steeply widening the gap between current expenses and revenues. Tables 4 gives the idea about the increasing gap on nation wide basis of Major and Medium projects. Besides, there is wider differences in surface water rates and the expenses involved in groundwater exploitation. In the case of groundwater pumping, one has to pay Rs. 125/- per month only for electricity charges per pumpset.

In the dry regions it is assumed that it can not supply water to more than one hectare. So the

Table 3

Water Rates (Rs./ha) for supply of water from government sources of irrigation in Andhra Pradesh.

\begin{tabular}{|l|l|l|}
\hline Nature of the crop & \multicolumn{2}{|c|}{ Water rate(Rs./ha) for } \\
& Category $-\mathrm{I} *$ source & \multicolumn{1}{|c|}{ Category - II ${ }^{* *}$ source } \\
\hline For first or single wet crop & 148.27 & 98.84 \\
\hline For second or third wet crop & 222.40 & 148.27 \\
\hline For first irrigated dry crop & 98.84 & 49.42 \\
\hline For second or third irrigated dry crop & 148.27 & 74.14 \\
\hline For dufasal\# crop in the fasli year@ & 370.67 & 247.11 \\
\hline
\end{tabular}

Note: * Any source of irrigation coming under Major and Medium Irrigation Projects shall come under category - I.

** Sources other than Major and Medium Irrigation sources shall come under category - II

\# Dufasal crop means a crop falls under two seasons

@ Fasli year means a period of 12 months commencing on first day of July every year

Source: Government of India, Planning Commission, Report of the Committee on Pricing of Irrigation Water, New Delhi, Sept. 1992, p.181.

Table 4

Revenues and Expenditures On Major \& Medium Irrigation Projects

\begin{tabular}{|l|l|l|}
\hline & \multicolumn{3}{|l|}{ (Rs. Billion in Constant 1980/81 Prices) } \\
\hline & $1980 / 81$ & $1988 / 89$ \\
\hline Current Revenues (Water charges) & 0.9 & $1.1(+29) \mathrm{a}$ \\
\hline Current Expenditures(non-plan) & 3.9 & $15.0(+280 \%) \mathrm{a}$ \\
\hline Capital Expenditures (Plan disbursements) & 14.0 & $18.3(+31 \%) \mathrm{a}$ \\
\hline Current Revenues as \% of Current Expenditures & $22 \%$ & $7.5 \%$ \\
\hline Capital (Plan) outlay as \% of Total & & \\
\hline Expenditures (Plan and non- Plan) & $78 \%$ & $55 \%$ \\
\hline
\end{tabular}

Source: Adapted from Reserve Bank of India Bulletins.

a Percent increase of $1988 / 89$ over $1980 / 81$ 
existing surface water rates are encouraging farmers to use only canal water as far as possible and discouraging conjunctive usage of water. In spite of low and subsidized water rates, actual revenue recoveries are substantially below than the demands(see Table 5). Large arrears have been allowed to accumulate and these tend to be eventually written off. The inefficiency of irrigation bureaucracy is further notified even in the water charges collections. The limited available data indicate us that wherever the Irrigation Department is solely incharge of assessment and collection of taxes, the accumulated arrears are more. The table above suggests that the ratio of accumulated arrears to annual demand is generally much higher in states where the Irrigation Department is responsible for both assessment and collection than where both functions are vested in the Revenue Department or where they are divided between the Irrigation and Revenue Departments. Since there is no linkage between the salaries of the employees and water charges collected, there is no compulsion on the part of the employees to collect charges and prove their abilities. ${ }^{19)}$

Table 5

Demand, collection and accumulated arrears of water rates in major states

(Rs. in million)

\begin{tabular}{|c|c|c|c|c|c|}
\hline State & $\begin{array}{l}\text { Responsibility for assessment } \\
\text { and collection }\end{array}$ & Period & Demand & Collections & $\begin{array}{l}\text { Accumulated } \\
\text { arrears }\end{array}$ \\
\hline Andhra Pradesh & Both by Revenue Department & 1986-87 & N.A. & N.A. & N.A. \\
\hline Bihar & Both with Irrigation Department & $\begin{array}{l}1986-87 \text { to } \\
1990-91\end{array}$ & 98.7 & 55.2 & 388.2 \\
\hline Gujarat & Both with Irrigation Department & $\begin{array}{l}1986-87 \text { to } \\
1990-91\end{array}$ & 102.5 & 73.9 & 385.6 \\
\hline Haryana & $\begin{array}{l}\text { Assessment by Irrigation Depar } \\
\text { tment and collection by } \\
\text { Revenue Department }\end{array}$ & $\begin{array}{l}1986-86 \text { to } \\
1990-91\end{array}$ & 112.6 & 113.8 & 103.4 \\
\hline Karnataka & Both by Revenue Department & $\begin{array}{l}1979-80 \text { to } \\
1981-82\end{array}$ & 6.5 & 5.9 & 15.0 \\
\hline Kerala & Both by Revenue Department & $\begin{array}{l}1979-80 \text { to } \\
1985-86\end{array}$ & 8.0 & N.A. & 6.8 \\
\hline Maharastra & $\begin{array}{l}\text { Both by Irrigation Department } \\
\text { since } 1976\end{array}$ & $\begin{array}{l}1986-87 \text { to } \\
1990-91\end{array}$ & 191.5 & 145.0 & 791.0 \\
\hline Madhya Pradesh & Both by Irrigation Department & $\begin{array}{l}1986-87 \text { to } \\
1989-90\end{array}$ & 234.0 & 144.5 & 806.5 \\
\hline Orissa & Both by Revenue Department & $\begin{array}{l}1986-87 \text { to } \\
1990-91\end{array}$ & 93.6 & 41.0 & N.A. \\
\hline Punjab & $\begin{array}{l}\text { Assessment by Irrigation Depar } \\
\text { tment and collection by } \\
\text { Revenue Department }\end{array}$ & $\begin{array}{l}1986-87 \text { to } \\
1990-91\end{array}$ & 99.1 & 104.4 & Nil. \\
\hline Tamil Nadu & Both by Revenue Department & $\begin{array}{l}1985-86 \text { to } \\
1989-90\end{array}$ & 33.9 & N.A. & N.A. \\
\hline Uttar Pradesh & $\begin{array}{l}\text { Assessment by Irrigation Depar } \\
\text { tment and collection by } \\
\text { Revenue Department }\end{array}$ & $\begin{array}{l}1986-87 \text { to } \\
1990-91\end{array}$ & 617.2 & 576.4 & 582.7 \\
\hline West Bengal & $\begin{array}{l}\text { Assessment by Irrigation Depar } \\
\text { tment and collection by } \\
\text { Revenue Department }\end{array}$ & $\begin{array}{l}1986-87 \text { to } \\
1990-91\end{array}$ & 23.7 & 7.5 & N.A. \\
\hline
\end{tabular}

Note:1. Figures for 1979-80 to 1981-82 relating to Karnataka and Kerala from Government Of India, Central Water Commission "Water Rates for Surface Water in India 1988". Data for Karnataka relates to Tungabhadra, Tungabhadra LBC and three small lift irrigation schemes. In other cases they relate to all major and medium irrigation schemes.

2. Demand and collection are the average per annum during the specified period. Accumulated arrears as at the end of the specified period.

Source: Government of India, Planning Commission, Report of the Committee on Pricing of Irrigation Water, New Delhi, Sept. 1992, pp.111-112. 


\subsubsection{Problems related to inter-state bureaucracy}

The Tungabhadra Board is responsible for managing the Right Bank Low Level Canal upto $250 \mathrm{kms}$. distance from the head region. The employees of the Board are drawn from both the states. Over-irrigation, misuse of water, unauthorized cultivation takes place mostly in the upper regions of the canal. In case the employee is native of Andhra Pradesh, he is scarred to take any action against the farmers of Karnataka because farmers bring regional feelings to safeguard their interests.

The above mentioned problems mostly related either to bureaucracy within or government's inaction and policy. It is easy for the government to solve these problems by initiating effective policies, creating sufficient facilities, making responsible and accountable bureaucracy, and reducing the burden on bureaucracy by transferring management partially to farmers.

\section{Conclusions}

As water rates are low and dues in collections, the recovery rates from irrigation investments is very low. At the same time, irrigation construction, operation and maintenance costs are increasing rapidly. A major portion of operation and maintenance costs are going to meet the salaries of the staff. The staff component has been increased from 34 percent in 1974-75 to 43 percent in 1986-87. ${ }^{20)}$ It can no longer be possible for any government to afford. Apart from increasing staff component in the irrigation maintenance, their contribution to irrigation efficiency has becoming negligible. Under these circumstances, there is no any option but to transfer part of aperation and maintenance activities to the users. But it is likely to difficult for farmers to take over much responsibility without an organization. ${ }^{21)}$ In India also from time to time there are some attempts to form Water
Users Associations(WUAs) and wants to transfer part of managerial responsibility to farmers. Till now only 1 percent of irrigated area is covered under such organizations. The failures are attributed to no clear-cut guidelines and lack of initiatives by the state. Now time has come to form such associations and delegate some managerial responsibilities to them.

For achieving efficiency in major and medium irrigation projects it is essential to create financially autonomous irrigation agency. The managerial agency should be like a corporation and its income should be dependent on the revenue it collects for irrigation service. ${ }^{22)}$ In order to create such an institution it is important to relate employees salaries with the collection of water rates. The water rates should be hiked upto 5 percent of gross production and some kind of balance should be maintained between groundwater pumping costs and surface water charges to promote conjunctive usage. Dues in collection should not be allowed. Moreover, special funds should be allotted to operation and maintenance activities by the central and state governments. In the future, facilities should be created to charge each farmer on the basis of volume rather than area.

Irrigation staff should be given considerable freedom in using finances and provided with better transport and communication facilities. In return, they are asked to show the results. Special training programs for the staff, promotion of coordination activities between farmers and staff should be organized and feed back mechanisms should be created. Special incentives should be provided to efficient and sincere employees.

Fines on water thieves, unauthorized cultivation and violators of cropping pattern should be imposed and collected. The amount of fine imposed should be left to the discretion of the officials. Clear guidelines are given to police to support irrigation staff in the case of violence by 
the farmers.

Future irrigation investments should concentrate on utilizing the existing potential rather than creating additional potential. The lining of all the canals including field channels, construction of balancing reservoirs, construction new tanks or repairs to old tanks should be taken up on priority basis. Moreover, plans should be prepared for exploiting groundwater on sustained basis.

\section{Notes}

1) Tungabhadra Board, Technical Report on Tungabhadra Project, vol.1, Tungabhadra Dam, p.45.

2) Kharif is monsoon crop grown from June to November.

3) Rabi is winter crop grown from December to April.

4) Mahesh C. Chaturvedi, Irrigation and Drainage systems policy analysis and India case study, Journal of Water Resources Planning and Management, vol.118, no.4, July/Aug., 1992, p.452.

5 ) Kathakali S. Bagchi, Irrigation in India: History and Potentials of Social Management, Upalabandhi, Delhi, 1995, p.XII.

6) M. Svendsen, and L.E. Small, Farmer's perspective on irrigation performance, Irrigation and Drainage Systems, vol.4, no.4, 1990, p.393.

7) Richard B. Reidinger, Water management by administrative procedures in an Indian irrigation system, in E. Walter Coward, Jr., (ed), Irrigation and Agricultural Development in Asia: Perspectives from the Social Sciences, Cornell University Press, London, 1980, p.265.

8 ) Svendsen, and Small, op. cit., p.395.

9 ) Ibid., p.394.

10) Asit K. Biswas, Monitoring and evaluation of irrigation projects, Journal of Irrigation and Drainage Engineering, vol.116, no.2, Mar/April. 1990, p.229.

11) A.F. Bottrall, Comparative study of the management and organization of irrigation projects, World Bank staff working paper no. 458, World Bank, 1981, p.156.

12) Charles W. Howe and John A. Dixon, Inefficiencies in Water project design and operation in the Third World: An economic perspective, Water Resources Research, vol.29, no.7, July 1993, pp.1891-92.

13) K. Gopalakrishnaiah, An integrated approach to command area development program, Indian Journal of Public Administration, vol.25, no.1, 1979, p.75.

14) Howe and Dixon,op. cit., p.1893.

15) Robert Wade, Irrigation reform in conditions of populist anarchy: An Indian case, Journal of Development Economics, vol.14, 1984, p.287.

Howe and Dixon, op. cit., pp.1890-91.

16) Robert Wade, The system of administrative and political corruption: Canal irrigation in South India, Journal of Development Studies, vol. 13, 1982, p.297.

17) Robert Wade, The management of irrigation systems: How to evoke trust and avoid prisoners' dilemma, World Development, vol.16, no.4, 1988, p.490.

18) Government of India, Planning Commission, Report of the Committee on Pricing of Irrigation Water, New Delhi, Sept. 1992, p.37.

19) Howe and Dixon, op. cit., p.1893.

Wade, The management of irrigation systems: How to evoke trust and avoid prisoners' dilemma, op. cit., p.493.

20) Central Water Commission, Financial aspects of multi-purpose river projects, May, 1990, p.125.

21) K. William Easter and Delane E. Welsch, Implementing irrigation projects: Operational and institutional problems, in K. William Easter, (ed) Irrigation Investment, Technology, and Management Strategies for Development, Westview Press, Colorado, 1986,p.43.

Robert C. Hunt, Appropriate Social Organization? Water User Associations in Bureaucratic Canal Irrigation Systems, Human Organization, vol.48, no.1, Spring 1989, p.79.

22) Ashok Gulati, et.al., Major and medium irrigation schemes: Towards better financial performance, Economic and Political Weekly, 25 June, 1994, p.A-77. 